\title{
Study Thought Ki Hajar Dewantara on The Concept of Character and National Education
}

\author{
Ana Mentari \\ Department of Civic Education \\ Indonesia University of Education, Bandung, West Java, Indonesia \\ Email: zahra_mahmudah12@gmail_com
}

\begin{abstract}
This article discusses the concept of character and national education of a person's nationality Indonesia national education leaders, Ki Hajar Dewantara. The concept of national character and education, the two concepts are independent from each other in the development of a dynamic society. The method used is the historical method, with a qualitative approach, as it aims to pour results of the study based on the arguments and in-depth understanding of the description. Ki Hajar Dewantara revealed that "national education should lead to a love of culture and psychotherapy (mental culture) itself". He also revealed that, a) teaching people to be excited abou the magnanimity of man; should therefore be concerned with all the value of psychotherapy (mental culture) and revive the spirit of idealism; b) teaching people to educate towards intelligence manners, the whole mental maturation (character building); c) teaching people to educate towards the family, which was jointly live, together thick and thin, jointly liable, etc; start a family in a small environment, to a large family (eg family of nations). Character education must be implemented with ngerti-ngroso-nglakoni (realized, comes to realize, and do).
\end{abstract}

Keywords: Ki Hajar Dewantara, Character, National Education

\section{Introduction}

The concept of national character and education, the two concepts are independent from each other in the development of a dynamic society. Society and the Indonesian people experiencing adversity in every field aspects of life [1]. One of the problems facing our education is a multidimensional crisis and the obvious degradation problems moral character of the nation, as well as issues of national disintegration that character education is considered tobe the powerful alternative solutions for dealing with problems of deteriorating morale of the nation. Other problems also triggered the moral problems because of their control of the media and the average family, as well as globalization and the cultural invasion from the outside to make the most of our younger generation who follow foreign cultures so that their own culture terkesampingkan.

Tilaar added one being the biggest problem of the 21st century is the emergence of awareness of the identity of a people or ethnic group [4]. Because it is caused by the presence of two great waves in social change, such as globalization and democracy. First, globalization will be able to threaten the nation's culture. Global culture will emerge and be able to turn off the local culture, and very dangerous. It is because of the destruction of local culture, means disintegration of the identity of a nation. Second, that the cause of the problem is the growing proliferation of national identity democracy. Democracy and identity are the two principles are complementary. According to Dahl [5], "one of the dangers or problems in a democratic society is the possibility of a conflict of cultures". problems in a democratic society is the possibility of a conflict of cultures ". Tempo daily tragedies noted some cultural conflicts in Indonesia are sourced for their cultural differences, including 1) Tragedy Sampit, this tragedy stems from the conflict between ethnic Dayak and Madura in Sampit, Central Kalimantan; 2) The Maluku conflict, violent conflict against the background of the religious differences between Muslims and Christians; and 3) Conflict of 1998, the economic crisis led into social conflict at the end of the New Order. Cultural conflict can be solved by mutual understanding between groups and the need for high tolerance each others. [6]

In line with the rapid development of the times, there are various moral issues that arise, including human rights violations and other forms of moral decline in others. There are several symptoms of moral decline, according Lickona, among others:

violence and anarchy increasingly rampant, theft, fraudulent activity, waiver of the applicable rules, the brawl between students, intolerance, use of language is not good, it is too early sexual maturity and deviation as 
well as the attitude of self-destruction. The symptoms of moral decline is a picture of neglect of the younger generation of moral sensitivity is a failure to reap serious problems concerning ethics in public life. [7]

While Mulyasa, mentioning that the problems of the nation today, include: [8]

- reoriented and not dihayatinya values of Pancasila as the philosophy and ideology of the nation;

- lack of an integrated policy tool in realizing the values of Pancasila essence;

- the shifting of ethical values in the life of the nation;

- the waning awareness of the cultural values of the nation;

- the threat of national disintegration;

- $\quad$ the weakening of the nation's independence.

Most of the symptoms of moral decline implies that the need for the nation's development through the development of cultural character local wisdom. Alwasilah asserted that "local and global thinking certainly has the distance of time, and a different concept; therefore, in need of reinterpretation pengejawantahannya intelligent, and it indicates that the value of having a dynamic power (values is dynamic force) ". [9] Ki Hajar Dewantara found, "all ethnic groups in the archipelago, has a culture respectively and has the great value of its own that can be developed and donated to build a national culture of Indonesia". [10]

$\mathrm{Ki}$ Hajar Dewantara is a figure that has a lot of writing to discuss the character of the nation as well as teaching and education on the basis of nationality. It is seen from one of the main objectives to be achieved by Tamansiswa, namely "to prepare human resources intelligently physically and spiritually, noble character, have a sense of nationalism, and a love of Indonesia, to form the Indonesian men are superior and character ". In addition, Ki Hajar Dewantara intended that national education non-discrimination, to be independent and free from influence of western education. It is the same with Romo Mangun and Ivan Ilich, who wants to change the purpose and process of education in schools aimed at the liberation of participants-students from various processes of indoctrination and jailing of creative thinking and innovative participant-learners. [11] Haryanto added that, "the principle and basic education initiated by Ki Hadjar Dewantara a solid foundation to build the character of the nation hinged on the nation's culture without neglecting foreign cultures". [12] Education in Indonesia should instill character and spirit of nationality derived from the nation's cultural roots and clearly based on Pancasila as the state ideology, philosophy and noble values of the nation.

\section{Research Methods}

The method used is a method of analysis-critical-historical-analytical or descriptive, with a qualitative approach, as it aims to pour results of the study based on the arguments and in-depth understanding of the description. According to Louis Gottschalk, revealed that "the historical method is the testing process and critically analyze the recordings relic of the past". [13] The writing of history (historiography) is a research about the procedure used historians in their research and replacement revision and interpretation of the past. [14] The historical method is generally the efforts of researchers to test and analyze critically the sources obtained from the thoughts and events of the past.

Operational steps descriptive-analysis method according Renier, 1961: 84, Ibrahim Alfan, 1997: 2, Allan Neris, 1962: 347, encompasses the following stages, including: [15]

- Heuristics, is an attempt to collect a source of Ki Hajar Dewantara of various kinds, both primary and secondary.

- Criticism of sources, an attempt to select all the data about Ki Hajar Dewantara already collected from various kinds. This step is done is to discover or verify the authenticity and credibility of the absence of data.

- Interpretation, namely the activities of analyzing the data that has been selected in order bring the facts of history, particularly in the fight and thought Ki Hajar Dewantara.

- Histriografi, is step by assembling the writing of historical fact in this case is a struggle and Ki Hajar Dewantara thinking logically, making manifest the paper systematic and chronological.

Qualitative data analysis in the study of critical leaders done through the following steps, among others: 1) find a pattern or theme; 2) looking for a logical relationship between the thought leaders in various fields so as to find reasons for the thought leaders; 3) clarify thinking in terms of making the grouping of characters that can be 
grouped into various areas as appropriate; 4) looking for specific ideas generalization. Some things to consider in analyzing the data, which includes 1) Researchers are expected not to make interpretations that exceed the information; 2) Researchers should not forget the limitations of the study; 3) code of ethics requires researchers to report issues that can affect the internal validity of the results obtained; 4) the data will be important if researchers are able to optimally carry out the analysis, so the results meet the scientific principles and acceptable. Study characteristics corresponding figures are qualitative, then the data analysis used is qualitative data analysis. The qualitative analysis will analyze the data descriptive narrative.

\section{Result and Discussion}

\subsection{Character}

Character movement is the unification of mind, feelings, and the will or volition, which into force. [16] This means that if the character is a blend of heart, if thought, sport, though the taste, and imagination, as shown below:

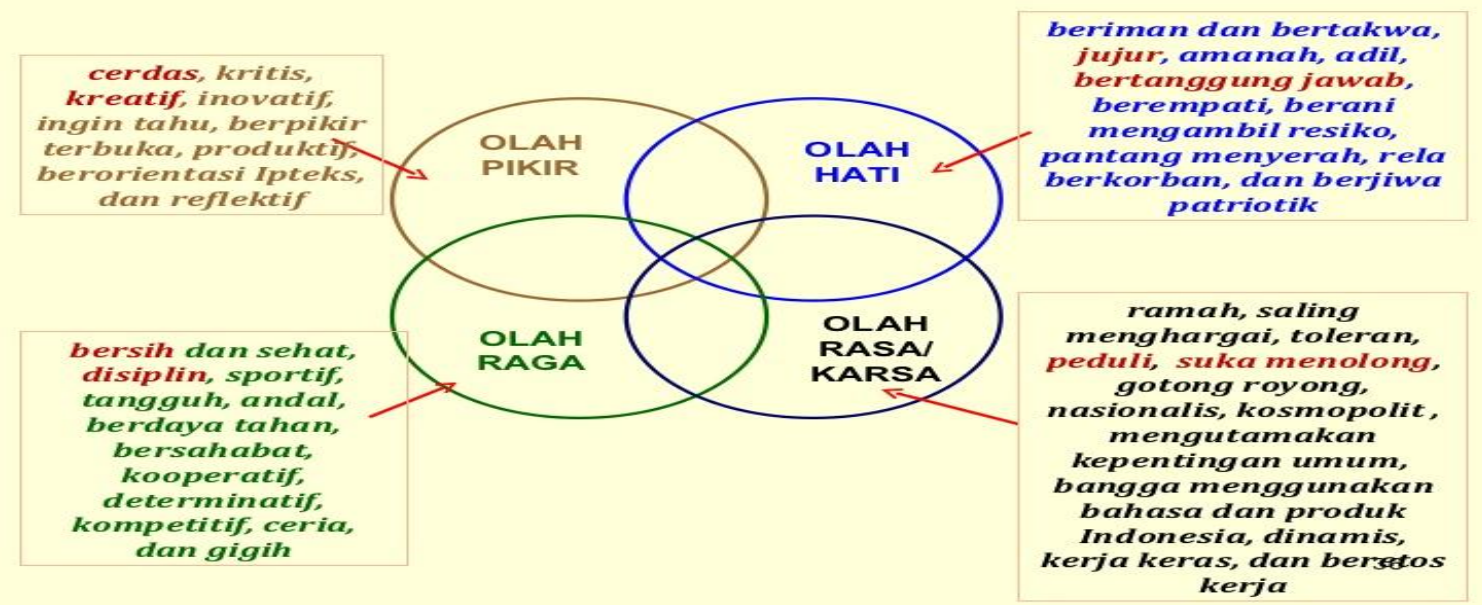

With the characters, then each man stands out as a free man (berperibadi), which can govern and master ourselves (self, zelfbehersching). Ki Hajar Dewantara, had argued a few things that must be implemented in character education, namely ngerti-ngroso-nglakoni (realized, comes to realize, and do). [10] Doctrine Ki Hajar Dewantara that illustrates the value of the character, including "Tetep-Mantep-Antep", "Ngandel-Kendel-BandelKandel", and "Neng-Ning-Nung-Nang", which became a force in the face of problems and difficulties faced. [16]

Character is not the result or product of business life but that will be more effective when people do something that becomes ability. Helen G. Douglas, said that "Character is not inherented. One builds its daily by the way one thinks and acts, thought by thougt, action by action ". [17] Therefore, the character is an important part in every individual.

\subsection{National Education}

National education is the most important of nation-building. According to Ki Hajar Dewantara character and national education in Indonesia is clearly different in Western countries. Furthermore, Carlos argued that, "the principle and basic education initiated by Ki Hajar Dewantara a solid foundation to build the character of the nation hinge on the nation's culture without neglecting foreign cultures". [12] Education in Indonesia should instill character and spirit of nationality derived from the nation's cultural roots and clearly based on Pancasila as the state ideology, philosophy and noble values of the nation. 
"Teaching should be nationality. If the teaching of children is not based on nationality, then the children may not have the love of the nation and increasingly detached from the people, then can be against us. National teaching because it is our right and duty ". [16] Ki Hajar Dewantara also revealed that, "national education should lead to a love of culture and psychotherapy (mental culture) itself." [16]

Dewantara also revealed that, a) teaching people to be excited about the magnanimity of man; should therefore be concerned with all the value of psychotherapy (mental culture) and revive the spirit of idealism; $b$ ) teaching people to educate towards intelligence manners, namely cooking whole soul (character building); c) teaching people to educate towards the family, which was jointly live, together thick and thin, jointly liable, etc; start a family in a small environment, to a large family (eg family of nations). [16]

Education nationalities held at Taman Siswa is teaching cultural nationalism that is in tune with the needs of society, the way of providing education nationalities done through ethical, cultural history, language lessons, art including, among other games, singing, dancing and music, youth. [18] Furthermore, Ma'ruf, argued that: [19]

The concept of national education can be seen like an educational renaissance Indonesia that aims to provide a balance between the level of intelligence, intelligence of the heart, and kinesthetic intelligence through integration with existing educational system up and running today. In the concept of nationality covers education, the concept of environmentally sound, sustainable development, equity and adequacy of access.

Essentially the concept of national education, in which there is nationalism, and patriotism. In addition, the concept of national education must adapt the concept of education according to UNESCO, of which fit the concept of education for all (education for all), life long learning (lifelong education), and education for sustainable development (education for sustainable development).

According to $\mathrm{Ki}$ Hajar Dewantara character and national education in Indonesia is clearly different in Western countries. "Teaching should be nationality. If the teaching of children is not based on nationality, then the children may not have the love of the nation and increasingly detached from the people, then can be against us. National teaching because it is our right and duty ". [16] Ki Hajar Dewantara also revealed that, "national education should lead to a love of culture and psychotherapy (mental culture) itself." [16]

Dewantara also revealed that, a) teaching people to be excited about the magnanimity of man; should therefore be concerned with all the value of psychotherapy (mental culture) and revive the spirit of idealism; b) teaching people to educate towards intelligence manners, namely cooking whole soul (character building); c) teaching people to educate towards the family, which was jointly live, together thick and thin, jointly liable, etc; start a family in a small environment, to a large family (eg family of nations). [16]

National education notion, Taman Siswa namely, education paved the lifeline of the nation (cultureelNationaal) and intended for livelihood (maatschappelijk) that can uplift the country and its people, in order working together with other nations for the glory of all men in the whole world. Do not forget that our nation has a culture that is not undervalued and colorfully its contents, including a variety of arts degree, also measured by international size. [16] Many of our national art-art that still should be maintained. Besides the maintenance of the arts which is a legacy of our ancestors were of high quality, we should also give the children everything new, which can enrich and develop life folk art we, though using ingredients from cultures of other nations.

\section{Conclusion}

Based on field findings described in the results and discussion, it can be concluded on any kind of research topics regarding national character and education, namely:

- Character is the merging of motion the mind, feelings, and the will or volition, which into force.

- Education teaching cultural nationalism nationality is aligned with the needs of society, the way of giving the national education done through ethical, cultural history, language lessons, art including, among other games, singing, dancing and music, youth. 
Because Indonesia is a nation with a great cultural diversity and uniqueness and the uniqueness of accompanying the national culture, but also open to the entry of a new culture of another nation with still have a love of the homeland and culture held. The new culture should not replace indigenous or local culture, but are unique in the diversity into global culture. The education process according to Ki Hajar Dewantara occur in the centripetal habitus, meaning centered on the local culture and gradually increased to more spacious environment to the national culture and even global culture. [11] This is the modern principle of education Tamansiswa, which since its inception has been familiar with the principles of multicultural education are rampant in the 21st century, to defend the values of character and nationality Education.

\section{Acknowledment}

Researchers say thanks Educational Fund Management Institution has provided assistance for the writing of this paper. Researchers also thank all those who have assisted in data collection in the field.

\section{References}

[1] Tilaar, H.A.R. Membenahi Pendidikan Nasional. (Cetakan Kedua). Jakarta: PT Rineka Cipta. 2009, pp. 116.

[2] Tilaar, H.A.R. Kekuasaan dan Pendidikan: Manajemen Pendidikan Nasional dalam Pusaran Kekuasaan. Jakarta: PT Rineka Cipta. 2009, pp. 19; Newsweek. Special Edition. July-September (2000). The New Asia.

[3] Tilaar, H.A.R. \& Riant Nugroho. (2009). Kebijakan Pendidikan: Pengantar untuk Memahami Kebijakan Pendidikan dan Kebijakan Pendidikan sebagai Kebijakan Publik. (Cetakan Kedua). Yogyakarta: Pustaka Pelajar.

[4] Eley, G., \& Ronald Grigor Sony (ed.). Becoming National, A Reader. New York: Oxford University Press. 1996.

[5] Dahl, Robert A. Perihal Demokrasi. Terjemahan. Jakarta: Yayasan Obor Indonesia, 2001, pp.203.

[6] Harian Tempo. 2015. Konflik yang Dipicu Keberagaman Budaya Indonesia. [Online]. diakses pada tanggal 1 Desember 2016.

[7] Lickona, Thomas. Educating for Character Mendidik untuk Membentuk Karakter Bagaimana Sekolah data Mengajarkan Sikap Hormat dan Tanggung Jawab. Jakarta: Bumi Aksara. 2015.

[8] Tilaar, H.A.R. Kebijakan Pendidikan: Pengantaruntuk Memahami Kebijakan Pendidikan dan Kebijakan Pendidikan sebagai Kebijakan Publik. (Cetakan Ketiga). Yogyakarta: Pustaka Pelajar. 2012. pp. 248.

[9] Alwasilah, A. Chaedar. Naskah Akademik: Etnopedagogi Sebagai Landasan Praktik Pendidikan dan Pendidikan Guru. (Cetakan Pertama). Bandung: Rizqi Press. 2009.

[10] Mulyasa, E. Manajemen Pendidikan Karakter. Jakarta: Bumi Aksara. 2014. pp. 56,1.

[11] Tilaar, H.A.R. (2012). Kebijakan Pendidikan: Pengantar untuk Memahami Kebijakan Pendidikan dan Kebijakan Pendidikan sebagai Kebijakan Publik. (Cetakan Ketiga). Yogyakarta: Pustaka Pelajar. 2012, pp. 27,56.

[12] Haryanto. 2011. Pendidikan Karakter Menurut Ki Hajar Dewantara. Jurnal. Cakrawala Pendidikan, Mei 2011, Th. XXX, 15-27. Edisi Khusus Dies Natalis UNY.

[13] Gottschalk, L. Pengantar Metode Sejarah. Jakarta: Universitas Indonesia. 1986, pp. 32.

[14] McMillan, James H. \& Sally Schumacher. Research In Education. New York: Longman Publishing. 2000, pp. 659.

[15] Syamsudin, Muh. Prof. Dr. H. M. Rasjidi: Perjuangan dan Pemikiran. Yogyakarta: Penerbit Azizah. 2004, pp.10.

[16] Dewantara, Ki Hajar. Pemikiran, Konsepsi, Keteladanan, Sikap Merdeka: Jilid I Pendidikan. (Cetakan Kelima). Yogyakarta: Penerbit Universitas Sarjanawiyata Tamansiswa (UST-Press) bekerjasama dengan Majelis Luhur Persatuan Tamansiswa. 2013, pp. 25,88,139,354.

[17] Samani, Muchlas. \& Haryanto. Konsep dan Model Pendidikan Karakter. Bandung: PT. Remaja Rosdakarya Offset. 2016, pp. 41.

[18] Soeratman, Darsiti. Ki Hajar Dewantara. Jakarta: Depdikbud.1985, pp. 84.

[19] Ma'aruf, Ahmad. 2013. Potret Pendidikan dan Kebangsaan di Indonesia. Jurnal. pp.25-31. http://jurnal.yudharta.ac.id/wp-content/uploads/2013/10/03.-Ahmad-Maruf_lengkap.pdf. 